\author{
Paweł Wiktor Ryś \\ Uniwersytet Jagielloński \\ pawel.w.rys@gmail.com
}

\title{
"Jeden przez dwa zostało podzielone”. Kobieta jako „inny” w Jeden Marcina Świetlickiego
}

\author{
“One Was Divided into Two." The Woman As the “Other” in Marcin Świetlicki’s \\ Jeden (One)
}

\begin{abstract}
The article concerns the image of the woman in Marcin Świetlicki's 2013 volume of poetry entitled Jeden (One), composed of "love stories." Femininity, for the speaker of the poems being a sort of "otherness" (understood here partly after Paul Ricoeur), presents itself as - on the one hand - a "mirror" for the "I", and - on the other hand - its indispensable ingredient. This is because Swietlicki's writing expresses the conviction that identity is as much a "positive" identification as (and maybe even chiefly) an identification done with regard to or through someone or something else. As a result of the constantly recurring necessity and need to distinguishing oneself, the woman seems to be both the condition and determinant of the "I" in Świetlicki's Jeden.
\end{abstract}

Keywords: Marcin Świetlicki, poetry, Jeden, other, woman

Streszczenie: Artykuł dotyczy obrazu kobiety w składającym się na „historie miłosne” tomie Jeden (2013) Marcina Świetlickiego. Kobiecość, będąca dla bohatera tych wierszy swoistą „innością" (rozumianą tu częściowo za Paulem Ricoeurem), jawi się - z jednej strony - jako „lustro” dla „ja”, z drugiej jako tegoż „ja” nieodzowny składnik. W twórczości Świetlickiego można bowiem dostrzec przekonanie, że tożsamość to zarówno identyfikacja „pozytywna”, jak i (a może przede wszystkim) określenie się względem kogoś/czegoś lub poprzez kogoś/coś. Konieczność i potrzeba - ciągle ponawianego - odróżniania się sprawia, że w Jeden to właśnie kobieta zdaje się warunkiem i determinantem „ja”.

Słowa kluczowe: Marcin Świetlicki, poezja, Jeden, inny, kobieta

Figura „innego” w poezji Marcina Świetlickiego pozostaje, jak postaram się dowieść $\mathrm{w}$ niniejszym artykule, ściśle sprzężona $\mathrm{z}$ dialektyczną konstrukcją podmiotu tych wierszy, z dialektyczną konstrukcją tekstowego „ja”. Jako że o owej dialektyczności wspominali już - choć za pomocą nieco innych 
terminów - niektórzy badacze, pozwolę sobie rozpocząć od dwóch cytatów. Pierwszy jest autorstwa Mariana Stali:

Świetlicki pokazuje siebie jako kogoś, kto nie daje się nazwać. Istotą tego nieuchwytnego Ja jest nieustanne odróżnianie się od innych, ciagła manifestacja odrębności... Albo prościej: fundamentem światoodczucia Świetlickiego jest powtarzanie światu słowa NIE ${ }^{1}$.

\section{Cytat drugi stanowi fragment recenzji Tomasza Majerana:}

Samookreślenie bohatera dokonuje się w opozycji do świata - i obojętne przy tym, czy będzie to świat wojskowych koszar, ulic Polski stanu wojennego, domu rodzinnego, dużej czy małej polityki. Nie ma odpowiedzi na pytanie: kim jestem? - jest natomiast szereg odpowiedzi na pytanie: kim nie jestem, w czym nie biorę udziału (bo nie chcę / nie mogę) $)^{2}$.

Przytoczone wyimki pochodzą z tekstów z początku lat dziewięćdziesiątych i zostały napisane jako komentarze do debiutanckich Zimnych krajów (1992). Niemniej można je odnieść zarówno do dowolnego tomu Świetlickiego, jak i do całej twórczości krakowskiego poety. Oczywiście, z jednej strony świadczy to o przenikliwości obydwu krytycznych głosów, ale z drugiej pokazuje, że istnieje coś, co wydaje się w poezji Świetlickiego (przy całej jej nieuchwytności) względnie stałe.

Względnie stałe są - jakkolwiek paradoksalnie to zabrzmi - właśnie niestałość oraz nieuchwytność „ja”. Podmiot wierszy Świetlickiego przyjmuje pewne kontury i zaraz je odrzuca. W każdym kolejnym utworze protagonista (nie) jest kimś innym, jest negatywem innej tożsamości. Bohater liryczny dookreśla siebie głównie przez odmienność, różnicę, zaprzeczenie, sytuuje się wobec, wbrew konkretnym postawom czy zjawiskom. Istnieje jedynie w odniesieniu do tego akurat bytu - tego, o którym mówi.

Mechanizm konstytuowania się podmiotu wierszy Świetlickiego przypomina nieco koncepcję Paula Ricoeura, który zauważa, że „inny” jest zarówno „lustrem” dla „ja”, jak i tegoż „ja” nieodzownym komponentem:

Inność, która nie pochodzi - bądź pochodzi nie tylko - z porównania (...), może tworzyć samo bycie sobą. (...) bycie sobą w przypadku siebie samego zakłada inność w stopniu tak głęboko wewnętrznym, że jedno nie daje się pomyśleć bez drugiego; że jedno przechodzi raczej w drugie $(. . .)^{3}$.

${ }^{1}$ M. Stala, Piosenka niekochanego [w:] tegoż, Druga strona. Notatki o poezji wspótczesnej, Kraków 1997, s. 193.

2 T. Majeran, Raport z zimnego miasta, „Odra” 1994, nr 9, s. 112.

${ }^{3}$ P. Ricoeur, O sobie samym jako innym, tłum. B. Chełstowski, Warszawa 2003, s. 9. 
Co więcej, teoria „innego” Ricoeura koresponduje także z otwartym, procesualnym i relacyjnym charakterem „ja” lirycznego analizowanej poezji. Jak zauważa bowiem Adriana Warmbier, komentatorka francuskiego filozofa: „polisemia inności, będąca składową procesu uświadomienia się sobie samemu oraz rozpoznania siebie, sprawia, że ontologia »tego-który-jest-sobą-samym-jak-i-innym " pozostaje niedomknięta, wymagając nieustannej pracy dookreślania"4.

Nie chcę przez to bynajmniej powiedzieć, że rozpoznania autora $O$ sobie samym jako innym są jakimś tajemnym kluczem do liryki twórcy Schizmy, ale że w omawianej poezji uchwytne jest przekonanie - które możemy zinterpretować za pomocą koncepcji wspomnianego filozofa ${ }^{5}$ - mówiące, iż tożsamość to zarówno identyfikacja „pozytywna”, jak i (a może przede wszystkim) określenie się wobec czegoś/kogoś lub poprzez kogoś/coś. Ten problem, niezwykle ważny dla współczesnej kultury, jest nieustannie przez Świetlickiego przepracowywany.

By dobrze pokazać związek między „ja” a „innym” w poezji krakowskiego twórcy, skupię się na jego jednym tomie, zatytułowanym Jeden. Opublikowany w 2013 roku został wydany w dość szczególnym momencie. Pojawił się jako pierwszy oryginalny tomik po zbiorowym wydaniu wierszy z $2011 \mathrm{i}$ ukazał się po czterech latach - co jak na Świetlickiego jest sporą przerwą - od wydania Niskich pobudek (czyli poprzedniego, dość chłodno przyjętego, zbioru $\mathrm{z}$ roku 2009).

Jeden posiada bardzo precyzyjną konstrukcję. Składa się z osiemdziesięciu ośmiu wierszy tworzących opowieść o roku (mniej więcej roku) z życia introwertycznego bohatera, mężczyzny, poety, Marcina. Wszystko rozpoczyna się od przedwiośnia, roztopów, a kończy nadejściem zimy. Poszczególne wiersze odnoszą się zaś do konkretnych pór roku, miesięcy, dni, tworząc liryczny dziennik. Ponadto drugi wiersz w tomie (Niespodzianka) przynosi obraz trupa ukrytego w topniejącym bałwanie („Wiosna przyjdzie. O, jak miło./ Trup w bałwanie") ), a utwór przedostatni, drugi od końca, zawiera wizję, w której podmiot liryczny ukrywa się „(...) wewnątrz bałwana” (I Marcinowi dobranoc, J, s. 91). Mamy więc coś w rodzaju kompozycji kołowej i zarazem uruchomienie - stale pojawiającego się w tej twórczości - motywu upiora ${ }^{7}$.

${ }^{4}$ A. Warmbier, O tzw. końcu podmiotu - wspótczesne rewizjonistyczne konteksty filozoficzne, „Zarządzanie Publiczne” 2014, nr 3, s. 52.

${ }^{5}$ Choć zapewne dałoby się wykorzystać tu jakąś - nomen omen - inną filozofię inności.

${ }^{6}$ M. Świetlicki, Niespodzianka [w:] tegoż, Jeden, Kraków 2013, s. 6. Dalej cytaty z Jeden będę lokalizował, podając tytuł wiersza ze skrótem J i numerem strony.

$7 \mathrm{Na}$ temat wspomnianego motywu w twórczości Świetlickiego napisano już sporo. Swoistym podsumowaniem tego wątku - przynoszącym jednocześnie istotne rozpoznania - jest artykuł Grzegorza Olszańskiego. Zob. tenże, Trup, który mówi [w:] Mistrz świata. Szkice o twórczości Marcina Świetlickiego, red. P. Śliwiński, Poznań 2011, s. 64-82. 
Już po powyższej, bardzo pobieżnej, charakterystyce (rok z życia mężczyzny, motyw upiora) widać, że w Jeden na plan pierwszy wysuwa się problematyka podmiotowości, jednostkowości, sposobu istnienia tożsamości. Bohater omawianej książki uobecnia się (podobnie jak w poprzednich tomach Świetlickiego) przez odróżnienie się od rozmaitych bytów, poglądów, kwestii. Występując przeciwko szeroko pojętej normatywności - jak w Śrubce („dalej się można golić, robić, spokój kazirodczy"; J, s. 11), modom intelektualnym („Wierutna brednia./ Droga uprzednia”; Chandler a gender, J, s. 61), czy czyniąc złośliwości pod adresem różnych osób. Przykładowo w wierszu Hycel, komornik, akwizytor („Mógłbym na przykład (...) zostać sekretarzem starego poety./ Wtedy dopiero byłoby niefajnie"; J, s. 86) znajdziemy aluzję do Michała Rusinka.

Jednocześnie też „ja” liryczne konstytuuje się, demonstrując swoją odrębność - niejako zbiorczo - wobec wszystkiego i wszystkich. Chociażby w wierszu Suche mejle podmiot liryczny wyznaje, że niezależnie gdzie się znajdzie, w jakim środowisku, zawsze czuje się samotny, nietożsamy z nikim, z niczym. „Między olbrzymami/ także jestem samotny. Pośród równych sobie/ też nie czuję się dobrze" (Suche mejle, J, s. 8). Widzimy tu więc - dobrze znanego z poprzednich tomów - outsidera, niechętnego jakimkolwiek formom zbiorowości i instytucjonalności, pielęgnującego swoją odrębność, zakładającego maski takich postaci (co znaczące), jak Werter, Pinokio, Batman, czy ostentacyjnie odwołującego się do motywu upiora lub flaneura ${ }^{8}$.

Figury inności w Jeden można by zresztą mnożyć9. Niemniej „innym”, który wydaje się w omawianym tomie szczególnie istotny i któremu chcę poświęcić nieco więcej uwagi, są kobiety ${ }^{11}$. Wspomniany rok z życia bohatera okazuje się bowiem w dużej mierze zdominowany przez historie miłosne ${ }^{12}$. W początkowych wierszach przewija się gdzieniegdzie słowo miłość, mowa o kochaniu, kochaniu się, a także o rozstaniu i byciu porzuconym. Ze sceny zdaje się schodzić jedna bohaterka i zjawia się inna, a wraz z nią zaskakujące epifanie (na przykład: „Idzie przede mną po schodach./ Jej nogi lśnią

${ }^{8}$ Na ten temat zob. P.W. Ryś, Wielość w jedności, „Fraza” 2013, nr 4, s. 262-265.

9 Jedną z nich jest niewątpliwie Bóg. Por. T. Naklicka, Paradoks Boga (na przyktadzie tomiku Marcina Świetlickiego „Jeden”) [w:] Nowa poezja polska wobec tradycji, red. S. Buryła, M. Flakowicz-Szczyrba, Warszawa 2015, s. 365-386.

${ }_{10}$ Por. J. Fazan, Jeden rok z życia mężczyzny (w najnowszym tomie Świetlickiego), „Nowa Dekada Krakowska” 2015, nr 1-2, s. 124.

11 Przy czym pragnę zaznaczyć, że kobiecość w Jeden będę badał tylko w kontekście „inności”, rozumianej po Ricoeurowsku jako warunek ,ja”. Pomijam natomiast (z drobnymi wyjątkami) socjologiczno-literacki wymiar obrazu kobiety. Próbę takiej analizy (choć niedotyczącą Jeden) podjęła już Magdalena Bednarek - por. taż, Kobieta, której nie ma [w:] Mistrz świata..., dz. cyt., s. 202-211.

${ }_{12} \mathrm{~W}$ Jeden mamy do czynienia raczej z historiami miłosnymi, a nie (jak sugerował Tomasz Kunz) z historią miłosną. Por. T. Kunz, „Osobność osobliwa”. Uwagi na marginesie tomu „Jeden” Marcina Świetlickiego, „Nowa Dekada Krakowska” 2015, nr 1-2, s. 119. 
od deszczu"; 3 lipca, gdzie indziej, w kosmosie, J, s. 39); pojawiają się utwory o wspólnym spędzaniu czasu czy tęsknocie spowodowanej tymczasową rozłąka.

Stała obecność kobiet na horyzoncie „życia” bohatera lirycznego sprawia, że stają się one podstawowym punktem odniesienia dla konstytuowania się jego podmiotowości. Jest to relacja tym bardziej interesująca, że z jednej strony „ja” liryczne uobecnia się wobec „innej”, z drugiej także poprzez „inną”, dzięki niej.

\section{Wobec kobiety}

Z tą pierwszą sytuacją mamy do czynienia w pierwszej części tomu, w której większość utworów poświęcona została końcowi miłości, rozstaniu i ich konsekwencjom. O sygnalizowanych wydarzeniach mówi się początkowo powściągliwie, nie wprost, między wierszami, jak na przykład w Światetku („on jeszcze kochać będzie, nie będzie kochany/ oraz kochany będzie”; J, s. 14) czy w tekście Caty w psie („Na czarnym/ (...) psia sierść (...). Widać z kim/ dziś spał"; J, s. 16). Utworem przełamującym ową zasadę jest Wyższa matematyka:

\section{I żadnego ratunku! Żadnej drogi odwrotu! \\ Wielka ulewa. Nie opuszczam domu, ale czuję, że dom mnie powoli opuszcza. \\ I żadnego ratunku! Cała pamięć w błoto i cała miłość w błoto (J, s. 17).}

Paradoksalny obraz powolnego opuszczania bohatera przez dom (który, jak okaże się w kolejnych wierszach, stanowi w Jeden synonim kobiety) sugeruje, iż zaistniałe wypadki odbywają się wbrew jego woli. Niemniej protagonista nie potrafi nic zrobić, o czym świadczy dwukrotne, nieco rozpaczliwe, wykrzyknienie. Puenta - zawierająca w dodatku trawestację sformułowania „cała miłość na marne"13 - uwydatnia jedynie patowy charakter sytuacji, w której znajduje się ,ja” liryczne.

Po Wyższej matematyce następuje wiele wierszy podejmujących omawiane zagadnienia w sposób mniej lub bardziej zawoalowany. Przykładowo w Ktopocie z mitościa czytamy: „Samotność przeziera./ To ona konstruuje ten dzień i ten tydzień” (J, s. 18), w Sienności: „Tuśmy się dostali/ i nie dojedziemy dalej” (J, s. 25), a w Od do: „Oddali się oddali. Od dali do dali/ się oddalali” (J, s. 28). Na szczególną uwagę zasługuje tu jednak 26 czerwca, wiersz, w którym uwypuklony został związek między rozpadem „dawnego świata” bohatera a rozdarciem ,ja”:

${ }^{13}$ M. Świetlicki, Marnowanie [w:] tegoż, Czynny do odwotania, Wołowiec 2001, s. 29. 
Klucz leży na podłodze. Znaczący ornament.

(...) $\mathrm{Na}$ dworzec. $\mathrm{Z}$ tych proponowanych przez tablicę ODJAZDY pociągów, kompletnie żaden nie nada się.

Bo nie jedzie się po to, by jechać. Się jedzie dokądś i po coś. Po dom. Po robotę.

Po kryjówkę. Po ciepło. Musi być spełniony przynajmniej jeden z wyżej wymienionych

warunków. W tym rozkładzie nie da się odnaleźć odpowiedniego miasta. A w tym tutaj mieście ja już nie jest. Ja siada na granicy torów, rozdziera się (J, s. 29).

Określenie celu ewentualnej podróży powoduje wyliczenie rzeczy, których podmiot nie znajduje już w swoim życiu. Zapowiedź rozstania (sygnalizowana przez klucz leżący na podłodze) oznacza bowiem koniec domu, kryjówki, ciepła. Wszystkie te elementy składają się na obraz nieobecnej. Co więcej, brak kobiety generuje zachwianie dotychczasowej formy istnienia protagonisty (,już nie jest”). Odejście „innej”, będącej częścią „ja”, doprowadza do rozdarcia. Granica torów stanowi tu symbol „rozejścia się” podmiotu (a także dwojga osób) w różne strony, w przeciwnych kierunkach.

W kolejnym wierszu, Nie się, padają następujące słowa: „kochać należy bez się, (...) się nie ma, jeśli kochać, wiesz?” (J, s. 30). Kończące utwór pytanie jest jednak - ponad wszelką wątpliwość - pytaniem retorycznym. Z Nie się sąsiaduje Jedność, w której poeta kontynuuje myśl o rozbiciu „ja”: „Zakłóciła się jedność między mną a mną./ Zakłóciła się, zbiegła, (...) już pewna nie jest/ swego istnienia" (J, s. 31). A po Jedności znajdziemy liryk She said, she said oddający (częściowo) głos kobiecie:

Bo ona powiedziała: nie rozumiem tego, że nie chcesz mnie rozumieć (...)

(...) zechciej zrozumieć mnie wreszcie.

Tak właśnie powiedziała: kiedy byłeś chłopcem, to rozumiałeś więcej, teraz się uparłeś i nie wiesz, nie chcesz, to ja ci wskazałam wszystkie wyjścia i wejścia, jestem prapoczątkiem

twojego końca (J, s. 32). 
Użycie mowy niezależnej staje się paradoksalnie chwytem ukazującym zależność mówiącej od cytującego ją podmiotu. Gestem sprawowania swoistej (patriarchalnej?) kontroli. Jakby bohater obawiał się tego, co powie kobieta, jakby musiał to wpierw przefiltrowywać przez samego siebie. Z przytoczonych słów wyłania się bowiem obraz mężczyzny nieumiejącego przyjąć kobiecej perspektywy, niechcącego podjąć trudu rozumienia. Coraz bardziej (wraz z upływającym czasem) zamkniętego w sobie, coraz mniej skłonnego do ustępstw i kompromisów. Złowrogo brzmiąca puenta, niezależnie już od tego, czy uświadamia bohaterowi jego śmiertelność (jak sugeruje Jarosław Fazan ${ }^{14}$ ), czy zapowiada koniec określonej formy istnienia, podkreśla główną rolę „innej” w konstruowaniu się i dekonstruowaniu podmiotowości ,ja” lirycznego.

Jako że prośba z She said, she said („zechciej zrozumieć mnie wreszcie”) nie może zostać spełniona, to następny utwór - For no one - porusza temat narastania obcości między bliskimi (kiedyś) osobami: „nie ma co się łudzić,/ nie ma co się i nie ma co ją, nie ma jej, jej język/ cię nie dotyczy, nie ma ciebie w jej/ języku, (...) ona/ nie ma już ciebie w żadnej swojej komórce" (J, s. 33). Chociaż w cytowanym wierszu podmiot uobecnia się przez negację, to i tak kluczowym ogniwem tego procesu okazuje się kobieta. Uwydatnienie jej chłodu („w jej oczach jest nic/ poniżej zera”; J, s. 33) korespondującego z chłodem przyrody („dzisiaj noc jest/ lodowata”; J, s. 33) wydaje się niejako odwróceniem konotacji przypisanych figurom mężczyzny i kobiety w She said, she said, dopełnieniem tamtego utworu przez zarysowanie męskiego punktu widzenia, odbiciem piłeczki. Wzajemna obcość bohaterów zasygnalizowana została ponadto przez zatytułowanie obydwu wierszy w obcym języku.

Dalej znajduje się - nomen omen - Skreślona dedykacja, w której czytamy, że „wszystko legło w gruzach” (J, s. 34), a po niej Rzucawka: „Naturalnie: nie umie przegrywać pogodnie,/ rzuca się porzucony i przerzuca się/ cytatami z niczego, tętniącymi w głowie" (J, s. 35). Autoironiczne sformułowania zawarte w przywołanych zdaniach wydają się próbą oswajania się podmiotu $\mathrm{z}$ nową sytuacją, sposobem na przepracowanie rozstania.

O zmianach i rewizjach mówi także - choć w nieco innym tonie - utwór Po remoncie:

Wierzyłem ślepo, że dom to kobieta, ale kobiety budują $\mathrm{w}$ domach nowe domy,

(...) zacierają ślady mężczyzn i wycierają się do sucha, aby już nie wracali (J, s. 36).

${ }^{14}$ Por. J. Fazan, dz. cyt., s. 124. 
Tytuł wiersza sugeruje, iż zawarte w nim wyznanie odbywa się po reorganizacji własnego wnętrza, reorganizacji wiążącej się z „kłopotem z miłością”. Znamienne więc, że wersy, w których „inna” wprost zostaje utożsamiona z domem, a co za tym idzie - z takimi wartościami, jak intymność, ciepło, bezpieczeństwo, operują czasem przeszłym. Zanegowanie wspomnianego porządku pozwala protagoniście wyartykułować zarzut o zawłaszczaniu wspólnej przestrzeni, ale przede wszystkim wytknąć kobiecie (po raz kolejny) jej niedostępność. Fragment o „wycieraniu się do sucha” - mimo że jednoznacznie uruchamia seksualne skojarzenia - mówi w szerszym znaczeniu o oschłości, braku czułości ze strony byłej partnerki.

Ostatnim utworem poruszającym wątek rozstania jest wiersz Proste:

I już nie ma dziewczyny

(...)

Stoi przed lustrem. Widzi

całą łazienkę. Nie siebie.

Siebie już nie ma w tym (J, s. 37).

Cytowany tekst zbiera w pewnym sensie wszystkie omawiane do tej pory zagadnienia: konstytuowanie się bohatera w relacji z „inną”, scalenie domu z kobietą, kobiecości z intymnością i rozproszenie „ja” w związku z zachwianiem się tych wartości. Rozbicie podmiotu sygnalizowane w poprzednich wierszach znajduje tu finał w postaci jego atrofii. Brak odbicia w lustrze uwydatnia bowiem upiorną kondycję bohatera, przejście w stan nieistnienia, zawieszenia. Odejście „innej”, fundamentu „ja”, powoduje swoistą dematerializację protagonisty. Dematerializacja ta wyrażona została (poza wspomnianymi obrazami) przez mówienie o sobie samym w trzeciej osobie liczby pojedynczej, które - zwłaszcza po intymnym wyznaniu z wiersza Po remoncie - staje się niejako monologowaniem z zewnątrz, spoza siebie.

Niemożliwość odnalezienia własnego ,ja” w wydawałoby się oswojonej przestrzeni („siebie już nie ma w tym”), każe widmowemu bohaterowi zawalczyć o nowe życie, o nową miłość. O podjęciu tego wyzwania mówi wyraźnie utwór Gotham, w którym protagonista wciela się w postać Batmana: „OPUSZCZAM GOTHAM/ Z KOBIETĄ KOTEM!/ TAK” (J, s. 38). Jednocześnie omawiany wiersz wchodzi w dialog z cytowanym wcześniej utworem 26 czerwca, z czego wynika, że tym razem istnieje szansa na spełnienie warunków podróży (dom, kryjówka, ciepło). Gotham rozpoczyna opowieść o nowej kobiecie, nowym życiu i mieszkaniu oraz o rozjazdach między tytułowym miastem (pod którym kryje się rzecz jasna Kraków i którego bohater bynajmniej nie opuszcza na stałe) a Wrocławiem, miastem ukochanej. Prezentowana historia będzie tu jednak - podobnie jak poprzednio - przede wszystkim 
opowieścią o konstytuowaniu się „ja ${ }^{15}$, w tym wypadku odbywającemu się na drugi ze wspomnianych wcześniej sposobów, już nie tyle wobec kobiety, ale właśnie poprzez nią, dzięki niej.

\section{Poprzez kobietę}

W następujących po Gotham wierszach mamy świadectwa pierwszych olśnień („,To jest specjalne światło”; 3 lipca, gdzie indziej, w kosmosie, J, s. 39), pierwsze deklaracje („przeciw upałowi zawzięcie kochamy”; 5 lipca, J, s. 40), oznaki pomyślnej aklimatyzacji w nowym miejscu („To teraz moje miasto, przynajmniej na te dni,/ kiedy tu będę"; 20 lipca, Wroctaw, J, s. 46), ale też sygnały ciągłej niepewności („Dziś się wydarzy. Oby nie złe. Oby/ nie ostateczne”; 21 lipca, J, s. 47). Mimo pojawienia się nowej kobiety bohater pozostaje przez dłuższy czas upiorem („I upiór staje w drzwiach ponownie”; Upiórczywośc, J, s. 44). Zapowiedź swoistego przełomu przynosi dopiero (dziesiąty, gdy liczy się od Gotham) tekst Nieczule:

Patrzę na tego człowieka nieczule.

(...) całkiem się tego człowieka wypartem.

Siedzę na krześle naprzeciwko niego.

nie jest mną. Jest zaledwie przegranym kochankiem.

A ja jestem dorosły. Robię. Podróżuję.

On trwa w wiecznym bezruchu. On wierzy, że wszystko

skończy się dobrze. Ja patrzę nieczule.

Przeżyłem koniec. Wiem, że się nie skończy

nigdy ten koniec (J, s. 48).

W cytowanym wierszu mamy rozdwojenie bohatera, mamy podział na kochanka i upiora (podmiot mówiący, że przeżył koniec, niewątpliwie przywołuje tę ostatnią figurę), ale jednocześnie konotacje obydwu motywów zostały zamienione miejscami. To, co zazwyczaj łączyło się w poezji Świetlickiego z uspołeczniającym działaniem miłości („,jestem dorosły. Robię. Podróżuję”), przypisano tu upiorowi, a to, co odnosiło się do upiora („wieczny bezruch”),

15 Wspomniana już Bednarek napisała - przed ukazaniem się omawianego tomu - następujące słowa: „Kobieta w poezji Świetlickiego okazuje się ciałem ograniczonym do kilku funkcji fizjologicznych, pozbawionym twarzy (...)" - taż, dz. cyt., s. 203. I choć pierwszy człon cytatu jawi się w wypadku Jeden jako nieobowiązujący, druga część wydaje się aktualna. Kobieta nadal „nie ma twarzy”, nawet jeśli stanowi (jak staram się tu dowieść) determinant „ja” lirycznego, to jej obecność jest istotna przede wszystkim ze względu na relację z męskim podmiotem, a nie ze względu na samą tę obecność. 
powiązano z kochankiem. Skąd ta zamiana? „Przegrany kochanek” uosabia oczywiście protagonistę z pierwszej połowy tomu, a mówiąc ściśle - jedno $\mathrm{z}$,ja” protagonisty, powstałe w wyniku „zakłócenia jedności”, niechcące się pogodzić z rozstaniem (figurę romantycznego nieszczęśnika). Podmiotem mówiącym jest zaś drugie „ja”, czyli zdematerializowany w utworze Proste bohater, który przybrał formę upiora i który - choć wchodzi już w nowy związek - nie zdołał się jeszcze całkiem wydźwignąć z upiorności, nie zdążył jeszcze zaistnieć. Upiór patrzy nieczule na „przegranego kochanka”, na dawną cząstkę siebie, odcina się od niej. Jego ostatnie słowa: „nie skończy się/ nigdy ten koniec", nawiązujące do puenty She said, she said (,jestem prapoczątkiem/ twojego końca”), podkreślają, że nie ma możliwości powrotu do tego, co było, nie ma nadziei na wznowienie tamtej miłości, na wskrzeszenie tamtego ,ja”.

Chociaż więc nowa historia rozpoczyna się od Gotham, to „powrót do żywych", odbudowa siebie sygnalizowane są dopiero w utworach następujących po wierszu Nieczule ${ }^{16}$. W tekście 30 lipca bohater wyjeżdża z Wrocławia; wraca do Krakowa, by tam przeprowadzić się do nowego mieszkania („z ło/ do bro”; Przeprowadzka, J, s. 55), by przygotować miejsce dla kobiety oraz - jedno wynika z drugiego - dla własnej „reaktywacji”. W wierszu $O$, dom! czytamy:

\section{(...) O, dom! Biorę! Chcę!}

Jest pusto! Kres podróży! Rzucam plecak w ką̨!

O, tędy wejdziesz! Bo po to są drzwi!

Więc biorę! O, dom! I jeżeli ty

istniejesz, dom istnieje! (...)

(...) I jeżeli mnie

jeszcze nie ma, to będę, siadam, staję się (J, s. 54).

Przywołany tekst stanowi rewers utworu Po remoncie, mówi o ponownym zawierzeniu wartościom, które kiedyś już zawiodły. Nie ma w nim jednak wzmianki o tamtym rozczarowaniu. W $O$, dom! znajdziemy - jak na rozpoczęcie kolejnego etapu przystało - euforię i nadzieję. Entuzjastyczne zapoznawanie się z nową przestrzenią jest oczywiście ściśle powiązane z przemeblowywaniem przestrzeni wewnętrznej protagonisty. W omawianym wierszu - tak jak i w poprzednich - dom pozostaje sprzężony z obecnością kobiety, ta ostania stanowi zaś warunek (za)istnienia bohatera, warunek jego powrotu do żywych. Sformułowanie „I jeżeli ty istniejesz, dom istnieje”, zawierające

16 Warto tu dodać, że jak obliczył Kunz (tenże, dz. cyt., s. 120), Nieczule jest czterdziestym czwartym wierszem w tomiku, co uwypukla romantyczną proweniencję wykorzystanych w nim motywów, a także jego istotne (domykające pierwszą część książki) miejsce. 
w sobie parafrazę wersu z dawnego wiersza Pogo („,kkoro/ ty zaistniałaś i ja już istnieję..." ${ }^{17}$ ), nierozerwalnie spaja ze sobą omawiane płaszczyzny.

Powstały z martwych bohater rozpoczyna więc - jak głosi tytuł jednego z tekstów - Nowe życie, którego centralnym punktem jest ukochana kobieta. Przekonanie o jej istotnej roli zostało wprost wyartykułowane w utworze $O$ :

Tę wąską, czarną gumkę, którą ściąga włosy, w nocy nosi na ręce, żeby nie zginęła, (...)

\begin{abstract}
Wyjechała, lecz wróci i niech wraca ciągle, niech ciagle powracają jej popołudniowe, poranne i wieczorne obyczaje, znowu
\end{abstract}

mam życie, ona mi je robi (J, s. 57).

Powtarzanie owego $\mathrm{O} w$ różnych konfiguracjach nie jest oczywiście przypadkowe. Jak można wnioskować z wiersza Senne siostrzyczki 2 („Ole, [...] wiele Ol”; J, s. 79), kryje się za nim inicjał imienia ukochanej ${ }^{18}$. Jej zachowania, zwyczaje, specyficzne gesty stają się tworzywem egzystencji bohatera. Dzięki nim zapowiedź z $O$, dom! („będę [...], staje się”) zostaje spełniona.

W kolejnych wierszach padają ważkie pytania („czy mnie kochasz?”; Trzeba pytać, J, s. 67), istotne wyznania („Moja płciowośćl określiła się”; Pan Bóg (Piosenka dla Mazzolla), J, s. 71), pojawiają się odpryski miłosnych tarć („Świt [...] sprowadza się do/ chaotycznych przeprosin"; Poker, J, s. 81), czy relacje ze wspólnie spędzonych chwil („Jesteśmy tutaj na spacerze, ona robi zdjęcia”; Niedziela w psychiatryczku, J, s. 84). Najważniejsze wydają się jednak - przynajmniej z przyjętej tu perspektywy - następujące utwory: Jeden dwa i Nielęk. W pierwszym z nich czytamy:

Ubrudziła spódnicę chińskim sosem, ojej!

Żadnych rozmów na temat, niedzielny hedonizm.

Pocałunek w policzek i do swoich domów.

Jeden przez dwa zostało podzielone (Jeden dwa, J, s. 62).

Utwór jest swoistym ciągiem kadrów, stopklatek, ukazujących dzień z życia bohaterów (życia przeciwstawionego w domyśle dawnej kondycji upiora). Posłużenie się sformułowaniem hedonizm do charakterystyki drobnych zdarzeń, niewinnych gestów czy zaniechania trudnych tematów podkreśla, iż dla bliskich sobie osób konstytutywne mogą być pozornie błahe sprawy. Tak

17 M. Świetlicki, Pogo [w:] tegoż, 49 wierszy o wódce i papierosach, Wrocław 2007, s. 22.

18 Por. J. Fazan, dz. cyt., s. 126. 
niewiele potrzeba, gdy ,jeden przez dwa zostało podzielone”. Przechodzenie „ja” w „inną”, ,innej” w „ja” ${ }^{19}$ zaakcentowane zostało przez wykorzystanie modelu liryki pośredniej, przez użycie w wierszu bezosobowej „narracji”. Jeden scalił się bowiem paradoksalnie (o czym mówi puenta) przez podział. Egzystencja stała się koegzystencją.

Jeszcze mocniej owe sensy wybrzmiewają w drugim wspomnianym wierszu - w Nielęku, będącym jednym z ostatnich utworów w tomie:

\section{(...) czasem}

czarne gadanie następuje, nocą

umieram, rano wstaję z mar i zmór.

I tak w kółko. Wiadomo, że kółko ma koniec,

kraniec, lecz teraz kręci się, śmiga, obraca

się pospiesznie. Końca nie widać.

(...) bo ty jesteś

pięknym mną, mną ciekawym, mną podniecająco

nieśmiertelnym i niech tak pozostanie jeszcze

przez jakiś bezczas (Nielęk, J, s. 88).

Tytułowy leksem sygnalizuje złożoność sytuacji lirycznej. Z jednej strony bohater (na chwilę obecna) ma pewność zarówno „swego istnienia”, jak i obecności („robiącej mu życie”) kobiety, z drugiej - doświadczenie (którego bynajmniej nie stara się wypierać) podpowiada mu, że „kółko ma koniec”. Dlatego też, mimo obecnego szczęścia, w tytule pojawia się - zaprzeczający obawom, ale całkowicie od nich niewolny - neologizm "nielęk” (a nie na przykład słowa błogość, spokój czy pewność). Życzenie o „bezczasowości” wyrażone w puencie zdradza właśnie czasowy, zmienny, relacyjny charakter fundamentu „ja”, którym zawsze pozostaje jakieś „ty”. Aporetyczne sformułowanie: „ty jesteś (...) mną", podobnie zresztą jak zdanie: ,jeden przez dwa zostało podzielone” z poprzedniego wiersza, wprost nazywa mechanizm uobecniania się ,ja” lirycznego w omawianym tomie (nie tylko w jego drugiej części). Parafrazując Ricoeura, można powiedzieć, że bohater Jeden jawi się jako ten, który jest zarówno sobą samym, jak i inną.

\section{Zakończenie}

Dialektyczny charakter „ja” lirycznego omawianej poezji (pozbawionego stałych rysów, cech) sprawia, że w tomie Jeden szeroko rozumiana „inna” zdaje się warunkiem sine qua non jego (za)istnienia. Niezależnie bowiem od tego, czy

19 Por. P. Ricoeur, dz. cyt., s. 9. 
omawiane wiersze poświęcone były rozdwojeniu protagonisty, czy jego scalaniu, podstawę ,ja” w obydwu wypadkach stanowiła kobieta.

Jednocześnie trzeba tu jeszcze podkreślić, że dialektyczność u Świetlickiego - mimo że niewolna od negatywów - nie jest siłą negatywną. Chociaż „ja” uobecnia się w tej poezji, jak starałem się to pokazać, zarówno wobec „nie-ja”, jak i poprzez „nie-ja”, to mechanizm dywersyfikacji jest zawsze mechanizmem konstytuowania się bohatera analizowanych wierszy.

Różnicowanie służy nie tyle wykluczeniu (choć czasem bywa i tak), ale przede wszystkim wyraża dążność do całkowej (aczkolwiek nieosiagalnej) odrębności podmiotu. Konieczność i potrzeba - ciągle ponawianego - odróżniania się sprawia, że „inny” stanowi w omawianej twórczości siłę sprawczą „ja”. W tym sensie poezja Świetlickiego jest - wbrew niektórym opiniom - poezją permanentnej „inności”. Niekończącą się historią o człowieku, który „budzi się codziennie w innym łóżku./ Jest innej płci, innej narodowości”20.

\section{Bibliografia}

Bednarek M., Kobieta, której nie ma [w:] Mistrz świata. Szkice o twórczości Marcina Świetlickiego, red. P. Śliwiński, Poznań 2011.

Fazan J., Jeden rok z życia mężczyzny (w najnowszym tomie Świetlickiego), „Nowa Dekada Krakowska” 2015, nr 1-2.

Kunz T., "Osobność osobliwa”. Uwagi na marginesie tomu „Jeden” Marcina Świetlickiego, „Nowa Dekada Krakowska” 2015, nr 1-2.

Majeran T., Raport z zimnego miasta, „Odra” 1994, nr 9.

Naklicka T., Paradoks Boga (na przyktadzie tomiku Marcina Świetlickiego „Jeden”) [w:] Nowa poezja polska wobec tradycji, red. S. Buryła, M. Flakowicz-Szczyrba, Warszawa 2015.

Olszański G., Trup, który mówi [w:] Mistrz świata. Szkice o twórczości Marcina Świetlickiego, red. P. Śliwiński, Poznań 2011.

Ricoeur P., O sobie samym jako innym, tłum. B. Chełstowski, Warszawa 2003.

Ryś P.W., Wielość w jedności, „Fraza” 2013, nr 4.

Stala M., Druga strona. Notatki o poezji wspótczesnej, Kraków 1997.

Świetlicki M., 49 wierszy o wódce i papierosach, Wrocław 2007.

Świetlicki M., Czynny do odwotania, Wołowiec 2001.

Świetlicki M., Jeden, Kraków 2013.

Świetlicki M., Niskie pobudki, Kraków 2009.

Warmbier A., O tzw. końcu podmiotu - wspótczesne rewizjonistyczne konteksty filozoficzne, „Zarządzanie Publiczne” 2014, nr 3.

${ }^{20}$ M. Świetlicki, A to jest zwyczajnie historia o cztowieku [w:] tegoż, Niskie pobudki, Kraków 2009, s. 7. 